\title{
Tinjauan Yuridis Penyesuaian Yayasan Yang Didirikan Sebelum Undang-Undang Nomor 16 Tahun 2001
}

\section{Delia Azizah Rachmapurnami}

Magister Kenotariatan Fakultas Hukum Universitas Islam Indonesia Yogyakarta Indonesia Jln. Cik Di Tiro No. 1 Yogyakarta Indonesia deliaazizah67@gmail.com

Key Word:

Adjustment, Foundation, Implications

\section{Abstract}

This study examines the problems of adjusting the Articles of Association of

Legal foundations that were established prior to the issuance of the Foundation Law, the implementation of the Deed of Adjustment of Foundations by a Notary, and the legal consequences arising from the Notary's error in making the Deed of Adjustment of the Foundation's Articles of Association. This is a juridicalnormative legal research method with a statutory approach and data collection through literature study with research analysis using descriptive-qualitative techniques. This study concludes, firstly, that there are still many Deeds of Adjustment to the Articles of Association of Foundations that were established before the issuance of the Foundation Law which have not been based on the Foundation Law and Government Regulation No. 2 of 2013. Second, due to the lack of understanding of the Notary in the laws and regulations, so that it is only limited to the Deed of Establishment of the New Foundation and then there are many wrong phrases related to Article 5 regarding "asset" and at the conclusion of the deed, as a result the Deed can be canceled or null and void. Third, clients can be subject to criminal sanctions and especially for Notaries can be subject to administrative sanctions, civil sanctions or criminal sanctions in accordance with applicable laws and regulations

Kata-kata Kunci:
Penyesuaian,
Yayasan, akibat
hukum

\section{Abstrak}

Penelitian ini mengkaji problematika penyesuaian anggaran dasar yayasan hukum Akta Penyesuaian Yayasan oleh Notaris, dan akibat hukum yang ditimbulkan atas kesalahan Notaris dalam membuat Akta Penyesuaian Anggaran Dasar Yayasan. Penelitian ini merupakan penelitian hukum yuridis-normatif dengan metode pendekatan perundang-undangan dan pengumpulan data melalui penelusuran literatur dengan analisa penelitian menggunakan teknik deskriptif-kualitatif. Penelitian ini menyimpulkan pertama, bahwa masih banyak ditemukan Akta Penyesuaian Anggaran Dasar Yayasan yang didirikan sebelum lahirnya Undang-Undang Yayasan yang belum mendasarkan pada Undang-Undang Yayasan dan Peraturan Pemerintah Nomor 2 Tahun 2013. Kedua, karena kurangnya pemahaman Notaris pada peraturan perundang-undangan, sehingga hanya sebatas dibuat Akta Pendirian Yayasan Baru dan kemudian banyak frasa-frasa yang salah terkait dengan Pasal 5 mengenai "kekayaan" dan pada penutup akta, akibatnya Akta dapat dibatalkan atau batal demi hukum. Ketiga, klien dapat dikenakan sanksi pidana dan terlebih bagi Notaris dapat dikenakan sanksi administratif, sanksi perdata ataupun sanksi pidana sesuai dengan peraturan perundang-undangan yang berlaku. 


\section{Pendahuluan}

Yayasan adalah suatu lembaga hukum yang bergerak di bidang keyakinan, kemanusiaan dan sosial dengan kekayaan yang terpisah serta tidak memiliki anggota. ${ }^{1}$ UU No. 28 Tahun 2004 tentang Perubahan UU No. 16 Tahun 2001 mengenai Yayasan, membutuhkan sesuatu ketentuan mengenai penerapannya, hingga dibentukIah Peraturan Pemerintah Nomor 2 Tahun 2013 tentang Perubahan Atas Peraturan Pemerintah Nomor 63 Tahun 2008 tentang Pelaksanaan Undang-undang tentang Yayasan. ${ }^{2}$ Dikeluarkannya PP No. 2 Tahun 2013 memberi kesempatan bagi Yayasan yang belum menyesuaikan Anggaran Dasarnya agar tetap eksis dan absah terkait kedudukan badan hukumnya.

Penyesuaian Yayasan yang didirikan sebelum Undang-Undang Yayasan yang dimaksud dalam hal ini adalah menyesuaikan akta pendirian atau anggaran dasar Yayasan yang didirikan sebelum adanya Undang-Undang Yayasan untuk disesuaikan dengan Undang-Undang dan/atau Peraturan Perundang-undangan lainnya yang berkaitan dengan Yayasan. ${ }^{3}$ Penyesuaian Yayasan dapat dilakukan dengan berdasarkan PP No. 2 Tahun 2013 Pasal 15A ataupun Pasal 37A.

Penyesuaian yang mendasarkan pada Peraturan Pemerintah No. 2 Tahun 2013 Pasal 15A yaitu berlaku dalam hal Akta Pendirian Yayasan di masa lalu yang tidak didaftarkan pada Pengadilan Negeri setempat. Sedangkan penyesuaian berdasarkan Pasal 37A yaitu berlaku kepada Yayasan di masa lalu yang Akta Pendiriannya sudah didaftarkan pada Pengadilan Negeri setempat. ${ }^{4}$

Akta Penyesuaian Yayasan yang mendasarkan pada Pasal 15A yaitu harus mendirikan Yayasan baru, tetapi tidak baru sama sekali, karena dalam premisse setelah komparisi disebutkan bahwa pendirian Yayasan baru tersebut adalah sebagai kelanjutan atau perubahan dari Yayasan yang didirikan sebelum adanya Undang-Undang Yayasan.

Penyesuaian yang benar yang didasarkan pada Pasal 37A, maka Notaris sebelumnya harus meminta pengurus Yayasan yang masih ada untuk mengadakan rapat pleno yang dihadiri lengkap oleh pengurus Yayasan, artinya pengurus Yayasan yang ada ketika penyesuaian siapa saja yang masih hidup dan tidak mengundurkan diri. Rapat pleno lengkap bertujuan untuk membentuk data Yayasan, yang artinya siapa yang didudukkan sebagai Pembina, Pengurus, dan Pengawas, setelah itu Notaris dapat membantu untuk notulennya.

Notaris berdasarkan Pasal 15 ayat (2) huruf c UUJN berwenang untuk memberikan penyuluhan hukum atas hukum rencana akta yang akan dibuat dihadapannya selaku Notaris. Notaris hendaknya tidak hanya berwenang tetapi juga berkewajiban untuk memberikan penyuluhan hukum kepada klien atas hukum yang termuat di dalam akta yang akan dibuat. Untuk perubahan Anggaran Dasar, memerlukan adanya persetujuan

1 Subekti dan Mulyoto, Yayasan Sebelum dan Sesudah Berlakunya Undang-Undang Yayasan dan Peraturan Pemerintah Nomor 63 Tabun 2008, Cakrawala Media, Yogyakarta, 2011, hlm. 1-2.

2 Mulyoto, Yayasan Kajian Hukum Di Dalam Praktek, Cakrawala Media, Yogyakarta, 2019, hlm. 1.

3 Subekti dan Mulyoto, Yayasan Solusi dengan Berlakunya PP. Nomor 2 Tabun 2013, Cakrawala Media, Yogyakarta, 2012, hlm. 11.

${ }^{4}$ Ibid., hlm. 52. 
dari Menteri, yaitu dengan cara Pengurus Yayasan melalui Notaris yang membuat aktanya mengajukan permohonan persetujuan kepada Menteri. ${ }^{5}$

Dalam prakteknya, terdapat berbagai problematika terkait penyesuaian Anggaran Dasar Yayasan oleh Notaris, dimana Notaris hanya sebatas membuat judul "Akta Pendirian Yayasan Baru" saja tanpa membuat Akta Penyesuaiannya, Notaris dalam membuat Akta Penyesuaian Yayasan seringkali tidak memasukkan kekayaan Yayasan lama, serta kesalahan pada penutup akta. Notaris dituntut agar menguasai dan mempunyai kemampuan dalam teknik pembuatan akta, supaya Notaris tampil professional. 6

Akibat ketidakpahaman Notaris yang bersangkutan dalam membuat Akta Penyesuaian tersebut maka dapat menimbulkan akibat hukum yang dapat merugikan para pihak yang terkait. Akibat hukum atas pembuatan akta yang jelas-jelas salah seperti itu tersebut dapat berakibat fatal terhadap akta, Notaris, dan penghadapnya.

\section{Rumusan Masalah}

Adapun permasalahan dalam penelitian berdasarkan latar belakang di atas yaitu, pertama, bagaimana implementasi Akta Penyesuaian Yayasan yang dilakukan oleh Notaris terhadap Yayasan yang didirikan sebelum Undang-Undang Nomor 16 tahun 2001? Kedua, bagaimana akibat hukum terhadap kesalahan Akta Notaris dalam Penyesuaian Yayasan lama dengan Undang-Undang Yayasan?

\section{Tujuan Penelitian}

Tujuan yang ingin dicapai berdasarkan latar belakang dan permasalahan di atas yakni, pertama, untuk mendalami dan menganalisis implementasi Akta Penyesuaian Yayasan yang dilakukan oleh Notaris terhadap Yayasan yang didirikan sebelum Undang-Undang Nomor 16 tahun 2001. Kedua, untuk memahami akibat hukum terhadap kesalahan Akta Notaris dalam Penyesuaian Yayasan lama dengan Undang-Undang Yayasan.

\section{Metode Penelitian}

Jenis penelitian ini menggunakan penelitian hukum yuridis normatif dengan cara meneliti perundang-undangan dan teori hukum kemudian dihubungkan berdasarkan fakta atau isu hukum yang ada. ${ }^{7}$ Metode dalam penelitian termasuk pendekatan perundang-undangan (statute approach). Analisa penelitian menggunakan teknik deskriptif-kualitatif yaitu menggunakan analisis dengan cara mendalami semua peraturan perundang-undangan yang berkaitan terhadap pokok permasalahan, untuk dicari keterkaitannya dengan isu hukum yang ada.

\footnotetext{
${ }^{5}$ Ibid., hlm. 33.

${ }^{6}$ Agus Pandoman, Teknik. Pembuatan Akta-Akta Notaris, Raga Utama, Yogyakarta, 2017, hlm. 3

${ }^{7}$ I Made Pasek Diantha, Metode Penelitian Hukum Normatif, Kencana, Jakarta, 2017, hlm. 156.
} 


\section{Hasil Penelitian dan Pembahasan}

\section{Implementasi Akta Penyesuaian Yayasan yang Dilakukan oleh Notaris terhadap Yayasan yang Didirikan sebelum Undang-Undang Nomor 16 Tahun 2001}

Yayasan adalah subjek hukum, karena subjek hukum adalah sesuatu yang dapat melakukan perbuatan hukum atau menjadi pihak/ subjek dalam hubungan hukum. ${ }^{8}$ Dengan berstatus badan hukum, maka perbuatan pengurus yang dilakukan atas nama yayasan, yang bertanggung jawab adalah yayasan. ${ }^{9}$ Dalam menyesuaikan Anggaran Dasar Yayasan yang didirikan sebelum adanya Undang-Undang Yayasan maka terdapat 2 opsi atau pilihan dalam membuat Akta oleh Notaris yaitu Penyesuaian dengan mendasarkan Pasal 15A Peraturan Pemerintah No. 2 Tahun 2013 dan Penyesuaian dengan mendasarkan Pasal 37A Peraturan Pemerintah No. 2 Tahun 2013.

Perbedaan antara Penyesuaian berdasarkan Peraturan Pemerintah No. 2 Tahun 2013 Pasal 15A dan Pasal 37A memiliki perbedaan sebagai berikut :

a) Penyesuaian berdasarkan Pasal 15A adalah ditujukan untuk Yayasan lama yang Akta Pendiriannya tidak didaftarkan di Pengadilan Negeri dan tidak diumumkan di Tambahan Berita Negara Republik Indonesia (TBNRI).

Sedangkan, penyesuaian berdasarkan Pasal 37A adalah ditujukan terhadap Yayasan yang telah diakui sebagai badan hukum.

b) Judul Akta Penyesuaian

Judul Akta Penyesuaian berdasarkan Pasal 15A adalah "Akta Pendirian Yayasan Baru", namun sebenarnya tidak baru sama sekali, yaitu tetap menyisihkan harta kekayaan Yayasan lama yang didirikan sebelum lahirnya Undang-Undang Yayasan yang juga dimasukkan sebagai kekayaan awal yang dinilai pada saat menjelang penyesuaian.

Sedangkan, judul Akta Penyesuaian berdasarkan Pasal 37A adalah "Pernyataan Keputusan Rapat (PKR)" atau dibuat "Berita Acara Rapat Pleno Lengkap Pengurus Yayasan".

c) Adanya Premisse

Perbedaannya adalah jika berdasarkan Pasal 15A ini terdapat bagian Premisse, yang menyebutkan asal usul Yayasan yaitu merupakan suatu kelanjutan atau perubahan dari Yayasan lama yang telah didirikan sebelum berlakunya UndangUndang Yayasan.

Sedangkan, berdasarkan Pasal 37A maka dalam Akta Penyesuaiannya tidak ada Premisse akta, tetapi yang perlu digaris bawahi adalah bunyi Pasal 5 dalam ayat (1) harus disebutkan mengenai jumlah harta kekayaan saat Yayasan pertama kali didirikan di masa lalu.

d) Penyesuaian berdasarkan Pasal 15A, Yayasan dengan tetap dimohonkan kepada Menteri guna mendapatkan Surat Keputusan (SK) Pengesahan sebagai badan hukum dari Menteri, jadi tidak hanya sebatas dilaporkan/ diberitahukan kepada Menteri saja.

${ }^{8}$ Hardijan Rusli, Hukum Perjanjian Indonesia Dan Common Law, Pustaka Sinar Harapan, Jakarta, 1993, hlm.

9 Taufik H. Simatupang, "Kedudukan Yayasan Yang Terbentuk Sebelum Lahirnya UU 28 Tahun 2004 Tentang Perubahan UU Nomor 16 Tahun 2001 Tentang Yayasan”, Jurnal Ilmiab Kebijakan Hukum Vol. 7 No. 1, Maret 2013, hlm. 9. 
Sedangkan berdasarkan Pasal 37A, Penyesuaian dari Menteri hanya Surat Penerimaan Pemberitahuan bahwa telah diterima, yaitu pemberitahuan dari Notaris melalui Penyesuaian.

Dalam prakteknya mengenai implementasi atau penerapan pembuatan Akta Penyesuaian Yayasan sebelum adanya Undang-Undang Yayasan, ternyata banyak ditemukan Notaris senior masih melakukan mal praktek atau pelanggaran hukum dalam pembuatan akta yang berkaitan dengan Yayasan. Kurangnya pemahaman dari Notaris sebagai pejabat umum terkait dengan akta yang diperbuat oleh atau dihadapannya masih menjadi masalah yang serius dalam Penyesuaian Yayasan. Kebanyakan Notaris pada umumnya belum sepenuhnya memahami hal atau isi Akta Perubahan Yayasan yang betul-betul benar secara hukum.

Ketidakpahaman dan ketidakprofesionalan ini dibuktikan dengan adanya kesalahan Akta Penyesuaian Anggaran Dasar dengan Undang-Undang Yayasan yang terjadi pada Yayasan Setia Hati Terate (SHT) yang didirikan di Madiun. Yayasan Setia Hati Terate adalah Yayasan yang bertujuan di bidang pendidikan.

Yayasan SHT awal mula didirikan adalah pada Akta Pendirian 12 November 1982 Nomor 55 oleh Notaris di Malang dan Akta Pendiriannya didaftarkan di Pengadilan Negeri Madiun pada 24 November 1982 dengan Nomor 11/leg/1982YYS.

Dalam Akta Penyesuaian yang dibuat di hadapan Notaris $X$ tersebut ternyata banyak sekali terdapat kesalahan dan tidak sesuai dengan aturan hukum mengenai Penyesuaian Yayasan yang didirikan sebelum lahirnya Undang-Undang Yayasan.

Kesalahan yang pertama adalah pada bagian judul Akta jelas salah, karena judul akta Penyesuaian yang tertera adalah "Akta Pendirian Yayasan Setia Hati Terate (SHT)". Seharusnya judul Akta Penyesuaian yang benar dalam kasus ini adalah "Pernyataan Keputusan Rapat" dengan mengadakan Rapat Anggota Organ seluruh organ Yayasan untuk kemudian menyesuaikan Anggaran Dasar Yayasan dengan Undang-Undang Yayasan dengan mendasarkan pada Peraturan Pemerintah No. 63 Tahun 2008 Pasal 37.

Apabila judul Akta adalah Akta Pendirian, maka seakan-akan Akta pada tahun 2014 tersebut sebatas Pendirian Yayasan Baru padahal yang dimaksud sebenarnya adalah Penyesuaian/Perubahan Anggaran Dasar yang merupakan kelanjutan dari Yayasan yang didirikan pada tahun 1982 tersebut.

Kesalahan yang kedua adalah pada Pasal 5 mengenai aset/ harta kekayaan yang dimiliki Yayasan Setia Hati Terate Notaris menyebutkan bahwa harta kekayaan yang dipisahkan adalah sebesar Rp. 28.163.600.000,00. Yayasan yang baru didirikan dengan harta kekayaan senilai jumlah tersebut amat sangat jarang terjadi. Secara materiil atau kenyataannya, sebenarnya kekayaan senilai Rp. 28.163.600.000,00 tersebut merupakan pengembangan yang berasal dari kekayaan Yayasan lama SHT.

Kesalahan yang ketiga masih terkait Pasal 5, dimana Notaris tidak pula mencantumkan harta/ aset kekayaan Yayasan Setia Hati Terate yang berupa tanah-tanah dan/atau bangunan pada Akta tertanggal 10-10-2014, dalam pasal tersebut hanya menyebutkan kekayaan awal Yayasan Setia Hati Terate pada 1982 saat Yayasan didirikan sejumlah uang sebesar Rp. 28.163.600.000,00. Notaris seharusnya merincikan dalam Pasal 5 terkait aset kekayaan Yayasan berupa apa saja, termasuk menyebutkan aset tanah- 
tanah dan/atau hak atas bangunan yang telah dimiliki oleh Yayasan SHT di masa lampau yang telah didirikan sebelum adanya Undang-Undang Yayasan.

Kesalahan yang keempat, adalah terdapat pada bagian "Penutup" akta. Dalam penutup Akta Pendirian Yayasan SHT tersebut tertulis bahwa Notaris mengajukan permohonan untuk memperoleh Surat Keputusan "Pengesahan" oleh Menteri. Frasa dalam penutup akta tersebut seharusnya Notaris cukup sebatas mengajukan permohonan Surat Penerimaan Pemberitahuan mengenai Akta Penyesuaian Yayasan yang telah diterima oleh Menteri berupa balasan surat. Surat Penerimaan Pemberitahuan tersebut sama nilainya dengan Surat Keputusan (SK) Pengesahan Yayasan sesuai dengan PP No. 2 Tahun 2013 Pasal 37A.

Jika Klien Notaris tidak memahami hukum sehubungan dengan perbuatan hukum yang dimuat dalam Akta Penyesuaian Yayasan yang dibuat Notaris itu masih dalam suatu batas kewajaran. Namun jika Notarisnya yang justru tidak memahami mengenai hukum dalam akta yang dibuatnya, itulah sesuatu yang fatal yang seharusnya tidak boleh terjadi. Notaris yang demikian sudah pasti tidak akan bisa memberikan penyuluhan hukum sebagaimana fungsi Notaris menurut UUJN, karena ia sendiri saja tidak paham dan sudah pasti berpotensi akan merugikan Klien atau pihak ketiga yang terkait.

Notaris harus bertanggungjawab penuh untuk melaksanakan kewajibannya dalam mengurus segala sesuatunya dari awal proses dibuatnya akta sampai dengan mengurus permohonan pengesahan akta pendirian Yayasan yang dibuatnya sampai kepada proses penerimaan pemberitahuan ataupun pengesahan akta oleh Menteri. Oleh karena itu, dalam membuat akta Notaris harus memahami hukum yang akan dimuat di dalam rencana akta yang akan dibuatnya.

Selain kekeliruan yang disebabkan Notaris, Korektor di Direktorat Jenderal Administrasi Hukum Umum (Ditjen-AHU)-Kementerian Hukum dan HAM RI idealnya tidak sebatas mahir mengoperasikan computer sehubungan dengan Sistem Administrasi Badan Hukum (SABH) sehubungan dengan Akta Notaris. Lebih dari pada itu mereka (korektor) seharusnya menguasai dengan baik dan benar mengenai ilmu pengetahuan hukum sebungan dengan Yayasan. ${ }^{10}$

Dalam hal ini Petugas Korektor berwenang melakukan pemeriksaan mulai dari dari akta-akta Pendirian oleh Notaris yang memerlukan pengesahan; akta-akta Notaris terkait Perubahan Anggaran Dasar Yayasan yang memerlukan persetujuan; sampai dengan akta Notaris yang sebatas cukup diberitahukan oleh Menteri dan apabila pemberitahuannya benar, kemudian dibalas oleh Menteri Hukum dan HAM RI bahwa pemberitahuan dari Notaris sehubungan dengan Yayasan tersebut telah diterima oleh Menteri. ${ }^{11}$

Petugas Korektor di Ditjen-AHU Kemenkumham yang menerima unggahan dan permohonan sehubungan dengan Akta-Akta Yayasan lewat SABH sehubungan dengan Akta Yayasan, baik itu permohonan pengesahan, permohonan persetujuan maupun sebatas pemberitahuan kepada Menteri tersebut seharusnya benar-benar berasal dari ahli

${ }_{10}$ Mulyoto, Yayasan Rumah Sakit Menjadi PT Rumah Sakit, Cakrawala, Yogyakarta, 2017, hlm. 38.

${ }^{11}$ Ibid., hlm. 40. 
Yayasan, jadi tidak hanya sebatas bisa mengoperasikan sistem online saja tetapi juga memahami regulasi sehubungan dengan Yayasan.

Ditemukannya banyak kesalahan yang terjadi pada Akta Penyesuaian oleh Notaris, maka membuktikan bahwa Akta tersebut tidak mendasarkan peraturan perundangundangan yang berlaku pada saat Klien menghadap dalam hal Yayasan yang dimaksud adalah Yayasan yang didirikan sebelum adanya Undang-Undang Yayasan dengan mendasarkan PP No. 2 Tahun 2013. Hal ini dapat menimbulkan kelemahan terkait posisi/ status Yayasan sebagaimana penjelasan di atas, mengakibatkan Yayasan yang baru disesuaikan tersebut kekuatan hukumnya menjadi kurang kuat terkait Legal Standing nya karena banyak terdapat kekeliruan dalam pembuatan Akta Penyesuaian.

Dengan demikian agar tidak terjadi kesalahan-kesalahan fatal yang seharusnya tidak terjadi, maka Notaris memang harus betul-betul mengerti mengenai rencana akta yang akan dibuatnya. Notaris harus mempunyai dasar pemikiran yang benar dulu, lalu berpijak kepada implementasi pelaksanaan pembuatan akta yang dibuat Notaris itu sendiri. Kemudian sangat penting bagi Notaris untuk menganalisis dan membedah kasus yang terkait, sehingga Notaris paham hal-hal apa saja yang merupakan termasuk kekeliruan atau kesalahan-kesalahan yang seharusnya tidak dilakukan oleh Notaris.

\section{Akibat Hukum terhadap Kesalahan Akta Notaris dalam Penyesuaian Yayasan Lama dengan Undang-Undang Yayasan}

1. Akibat Hukum Pada Akta

Apabila di kemudian hari terdapat kesalahan/ sengketa terkait Akta Penyesuaian Yayasan yang didirikan sebelum adanya Undang-Undang Yayasan oleh Notaris, maka akta tersebut dapat dinyatakan tidak sah dan tidak memiliki kekuatan hukum yang mengikat maupun batal demi hukum.

2. Akibat Hukum Pada Klien

Klien dapat dianggap telah menguasai aset Yayasan lain tanpa hak. Sesuai dengan hukum dasar Yayasan bahwa segala tindakan organ Yayasan termasuk pengalihan aset-aset Yayasan seharusnya sebatas untuk tercapainya maksud dan tujuan Yayasan, bukan sebatas untuk kepentingan pribadi dari pihak Pembina Yayasan yang kemudian mengalihkan semua aset Yayasan atau menjual Yayasan tersebut kepada sebatas seseorang. Maka hal demikian merupakan tindak pidana terkait penguasaan aset tanpa hak. ${ }^{12}$

Klien dapat dianggap melakukan tindak pidana Pemalsuan NPWP. Klien dapat dikenai tindak pidana Pemalsuan NPWP apabila pada saat Klien menghadap ke Notaris yang membuat Akta Pendirian Yayasan Baru atau Akta Penyesuaian Yayasan, anggota organ Yayasan yang bersangkutan diketahui menggunakan NPWP Yayasan lama yang artinya seharusnya NPWP Yayasan lama tidak ada kaitannya dengan NPWP Yayasan Baru yang akan disesuaikan. Jika terjadi hal demikian maka jelas termasuk melakukan tindak pidana terkait Pemalsuan NPWP. ${ }^{13}$

\footnotetext{
12 Mulyoto, Yayasan Kajian Hukum Di Dalam Praktek, Op. Cit., hlm. 67.

${ }^{13}$ Ibid.
} 
Klien bisa saja mendapatkan masalah dalam perpanjangan masa berlakunya Hak Guna Bangunan (HGB) atas bidang-bidang tanah yang dimiliki Yayasan lama yang didirikan sebelum lahirnya Undang-Undang Yayasan. Terhadap akibat hukum ini dapat merugikan Klien apabila Notaris hanya sebatas membuat Akta Pendirian Baru bukan Penyesuaian Anggaran Dasar Yayasan yang benar. Apabila Yayasan lama yang telah memiliki harta kekayaan berupa beberapa bidang tanah dengan status kepemilikan hak adalah dengan HGB yang diperoleh oleh Yayasan di masa lalu sebelum lahirnya Undang-Undang Yayasan. Namun jika Notaris hanya mengambil jalan mudahnya saja dengan tidak berdasarkan hukum/ketentuan hukum yang berlaku maka tentu saja hal ini amat sangat dapat merugikan Klien. Klien atau Pengurus Yayasan dapat mengalami kesulitan untuk memperpanjang masa berlakunya HGB atas bidang-bidang tanah yang dimiliki Yayasan, sehingga permohonan perpanjangan masa berlakunya HGB Yayasan yang bersangkutan tidak dapat dikabulkan.

Bila dihubungkan dengan teori pertanggungjawaban hukum, jika Yayasan melakukan perbuatan yang melanggar hukum maka menurut hukum seluruh anggota organ badan yayasan tersebut harus bertanggungjawab secara renteng sebagai akibat dalam menanggung kerugian yang telah ditimbulkan oleh badan Yayasan tersebut.

3. Akibat Hukum Pada Notaris

Akibat hukumnya, Notaris dapat dikenakan sanksi perdata, yaitu dapat digugat membayar biaya ganti rugi, bunga, dan biaya apabila penghadap atau pihak ketiga merasa telah dirugikan oleh Notaris.

Notaris dapat dikenakan sanksi administratif menurut ketentuan Pasal 85 UndangUndang Jabatan Notaris antara lain teguran lisan, teguran tertulis, pemberhentian sementara, pemberhentian dengan hormat, pemberhentian dengan tidak hormat tergantung kepada bobot berat atau tidaknya kesalahan Notaris serta berapa kali jumlah melakukan pelanggaran.

Bahkan Notaris dapat dikenai sanksi pidana berupa hukuman penjara, apabila terbukti melakukan pemalsuan Akta Penyesuaian Yayasan. Hal tersebut dapat mengakibatkan Yayasan tidak lagi memiliki Legal Standing untuk menjadi Badan Hukum dalam melaksanakan kegiatannya.

Berdasarkan teori pertanggungjawaban, maka Notaris wajib bertanggungjawab sebagaimana telah diatur dalam Undang-Undang Jabatan Notaris Pasal 15, yaitu memberikan penyuluhan hukum sehubungan dengan rencana pembuatan akta. Artinya Notaris tidak hanya sekedar mengikuti apa yang dikehendaki oleh Penghadap, tetapi harus ada ilmunya. Dengan kata lain apabila Notaris tidak paham dan tidak professional maka dapat menimbulkan akibat hukum seperti hal di atas.

Yayasan dalam melakukan kegiatas usahanya harus berdasarkan asas transparansi, asas akuntabilitas, dan publisitas termasuk kewajiban pemerintah untuk mempublikasikan peristiwa hukum menyangkut hak informasi umum maupun hak perorangan, dan informasi yang sifatnya mengikat umum. ${ }^{14}$

14 Agus Pandoman, Hukum Kontrak Online Kontrak Tidak Bersentuban, Putra Surya Santosa, Yogyakarta, 2020, hlm. 210. 


\section{Penutup}

Implementasi Akta Penyesuaian Yayasan yang dilakukan oleh Notaris terhadap Yayasan yang didirikan sebelum Undang-Undang Yayasan membuktikan bahwa masih banyak Notaris senior belum memahami bagaimana cara membuat Akta Penyesuaian dengan mendasarkan pada Peraturan Pemerintah No. 2 Tahun 2013. Dalam prakteknya masih terdapat banyak sekali Notaris yang melakukan kesalahan fatal dengan membuat judul sebatas "Akta Pendirian Yayasan Baru". Notaris seringkali juga menyebutkan harta kekayaan awal yang disisihkan tiba-tiba sejumlah milyaran, padahal dalam kasus yang bersangkutan harta tersebut merupakan pengembangan dari kekayaan atau aset dari Yayasan lama (yang didirikan sejak tahun 1982). Dan masih banyak kasus Notaris dalam membuat Akta Penyesuaian dimana frasa-frasa atau isi dalam aktanya tidak mendasarkan pada Peraturan Pemerintah No. 2 Tahun 2013 Pasal 37A dan/atau Pasal 15A.

Akibat hukum terhadap kesalahan Notaris dalam Penyesuaian Yayasan dengan Undang-Undang tentang Yayasan dapat menimbulkan akibat hukum pada Akta, Klien, dan Notaris. Akibat Hukum pada Akta jika Notaris hanya sebatas membuat Akta Pendirian Yayasan Baru maka Akta tersebut dianggap sama sekali bukan merupakan kelanjutan atau perubahan dari Yayasan yang didirikan sebelum berlakunya UndangUndang Yayasan. Akibat hukum pada Klien, Klien bisa saja dianggap telah melakukan pembohongan publik, menguasai aset Yayasan lain tanpa hak, melakukan tindak pidana Pemalsuan. Akibat hukum pada Notaris, Notaris dapat dikenai sanksi administratif, sanksi perdata, dan sanksi pidana.

\section{Daftar Pustaka}

\section{Buku}

Diantha, I Made Pasek, Metode Penelitian Hukum Normatif, Kencana, Jakarta, 2017.

Mulyoto, Yayasan Kajian Hukum Di Dalam Praktek, Cakrawala, Yogyakarta, 2019. Yayasan Rumah Sakit Menjadi PT Rumah Sakit, Cakrawala, Yogyakarta, 2017.

Pandoman, Agus, Teknik Pembuatan Akta-Akta Notaris, Raga Utama, Yogyakarta, 2017. Hukum Kontrak Online Kontrak Tidak Bersentuhan, Putra Surya Santosa, Yogyakarta, 2020.

Rusli, Hardijan, Hukum Perjanjian Indonesia Dan Common Law, Pustaka Sinar Harapan, Jakarta, 1993.

Subekti dan Mulyoto, Yayasan Sebelum dan Sesudah Berlakunya Undang-Undang Yayasan dan Peraturan Pemerintah Nomor 63 Tahun 2008, Cakrawala Media, Yogyakarta, 2011

Yayasan Solusi dengan Berlakunya PP. Nomor 2 Tahun 2013, Cakrawala Media, Yogyakarta, 2012.

\section{Jurnal}

Taufik H. Simatupang, "Kedudukan Yayasan Yang Terbentuk Sebelum Lahirnya UU 28 Tahun 2004 Tentang Perubahan UU Nomor 16 Tahun 2001 Tentang Yayasan", Jurnal Ilmiah Kebijakan Hukum Vol. 7 No. 1, Maret 2013 
ISSN: 2776-5458 EISSN: 2808-2613

Delia Azizah Rachmapurnami. Tinjauan Yuridis Penyesuaian Yayasan... 369

\section{Peraturan Perundang-undangan}

Undang-Undang Nomor 2 Tahun 2014 tentang Jabatan Notaris

Undang Undang Nomor 16 Tahun 2001 tentang Yayasan

Peraturan Pemerintah Republik Indonesia Nomor 2 Tahun 2013 tentang Perubahan atas Peraturan Pemerintah Nomor 63 Tahun 2008 tentang pelaksanaan Undang Undang Yayasan. 